Bu makaleye atıfta bulunmak için/To cite this article:

GÜZEL, K. (2021). Çağdaş İrlanda Tiyatrosunda Brendan Kennelly'nin Medea Yorumu. Atatürk Üniversitesi Sosyal

Bilimler Enstitüsü Dergisi, 25 (4), 1537-1551.

\title{
Çağdaş İrlanda Tiyatrosunda Brendan Kennelly'nin Medea Yorumu
}

Kader $G \ddot{U} Z E L^{(*)}$

Öz: Mitosların ve işlendikleri oyunların kültürel etkileri günümüzde de kendisini göstermektedir. Antik çağdaki kültürel ögeler ve insanlar arasındaki ilişkiler ve problemler, günümüzde yaşananlara benzerlik göstermektedir. Bu yüzden mitosların temelini oluşturduğu, tiyatronun dönüm noktalarından biri olan Antik Yunan oyunları birçok yazara hala ilham vermektedir. Bunlardan birisi de Euripides'in yazmış olduğu Medea adlı oyundur. Güncelliğini kaybetmeyen oyun, toplumda var olan çatı̧̧maları, manevi yükümlülükleri, kadın-erkek ilişkisini, tanrısal gücü, duygusal bağlarl ve ötekileştirmeyi içermesiyle çağdaş dönemde de güncelliğini korumakta ve izleyicisine hitap etmektedir. Bu çalışmada, Euripides'in Medea adll oyununun güncel bir çevirisi olan, Brendan Kennelly'nin Medea yorumu incelenmektedir. Yazarın düşünceleri ve yaşam tarzıyla şekillenen bu yeni varyasyonda, Irlanda'nın geçirmiş olduğu süreçlerin bu ülkenin vatandașları üzerindeki etkileri Medea'nın yașadıklarıyla bağdaștırılarak sunulmuştur. Bu çalışmada amaç, Brendan Kennely'nin Medea yorumlamasını Euripides'in Medea oyunuyla karşılaş̧tırarak incelemek ve politik yapılanmalardan geçen bir ülkenin durumunu irdeleyip ötekileştirme ve cinsiyet sorununa dikkat çekmektir.

Anahtar Kelimeler: Medea, Euripides, Brendan Kennelly, Irlanda, ötekileştirme, kadın.

\section{Brendan Kennelly's Interpretation of Medea in Contemporary Irish Theatre}

Abstract: The cultural effects of myths and the plays in which they are performed are still evident today. Cultural elements and relations between people and problems in ancient times resemble those experienced in contemporary period. That is the reason behind the fact that the plays which were based upon myths and written during Ancient Greek period still inspire many playwrights. One of them is Medea written by Euripides. The play, including the conflicts, spiritual obligations, male-female relationship, divine power, emotional ties and othering in society, perpetuates its actuality and appeals to the contemporary audience. This study examines Brendan Kennelly's interpretation of Medea, a current translation of Euripides' play, Medea. In this new adaptation, which is shaped by the thoughts and lifestyle of the author, the effects of the processes that Ireland has gone through on the citizens of this country are presented with special attention to Medea's experiences. The purpose of the study is to analyse the reinterpretation of Medea through comparing it with Euripides' Medea in order to examine the conditions of a country going through political structures and to draw attention to the othering and gender issue.

Keywords: Medea, Euripides, Brendan Kennelly, Ireland, othering, woman.

Makale Geliş Tarihi: 29.06.2021

Makale Kabul Tarihi: 21.12.2021

DOI: 10.53487/ataunisosbil.959236

\footnotetext{
*) Arş. Gör., Muş Alparslan Üniversitesi Fen Edebiyat Fakültesi İngiliz Dili ve Edebiyatı Bölümü (e-posta: k.mutlu@alparslan.edu.tr) (D) ORCID ID. https://orcid.org/0000-0001-9277-2128

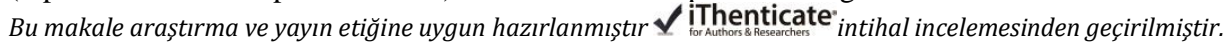




\section{Giriş}

İrlanda'nın en verimli ve popüler şairlerinden biri olan Brendan Kennelly, profesör olarak çalıştığı Trinity Üniversitesi'nden 2005 yılında emekli olmuştur. Otuzdan fazla şiir kitabı bulunan Kennelly, çok sayıda antolojiye editörlük yapmıştır. The Crooked Cross (1963) ve The Florentines (1967) adlı romanların da yazarıdır. Eserlerini yazarken sade bir dil kullanan Kennelly, ülkesinin içinden geçtiği zorlu dönemleri anlatmış, eserlerinde İrlanda halkını bilinçlendirmeye ve cesaretlendirmeye yönelik simgelere yer vermiştir. Kennelly, İrlanda toplumunu ve kadının toplumdaki yerini Antik Yunan trajedilerini yeniden yorumlayarak analiz etmiştir. Eserlerini oluştururken, Yunan mitolojisi ve Antik Yunan toplum yapısından faydalanmıştır. Trajedilerdeki güçlü kadın karakterleri analiz etmiş ve onları İrlanda kadınıyla bağdaştırmıştır. Savaş, otoriter rejimler ve aile içi çatışmalar sonucunda hayatları bölünen kadınları odak noktası yapan Sophocles'in Antigone (İ.Ö. 440) adlı oyununu ve Euripides'in Medea ve Troyalı Kadınlar (İ.Ö. 415) adlı oyunlarını, İrlanda toplumunun yapısına uyarlayarak günümüze taşımıştır. Ona göre: "Mitik drama hem yakında hem de uzaktadır. Yakınlığı, günümüzdeki yazarların eskiye bakmasını ve onu günümüze ve günümüz problemlerine bağlamasını sağlamıştır” (Kennelly, 2006: 7). Yazar, mitosların kaynaklık ettiği bu eserleri incelerken, yaşadığ analiz etme fırsatı bulur. Böylece kendi yorumunu kattığı eserini oluştururken geçmiş ve şimdiki zaman arasında da bir bağ kurmuş olur. Euripides'in Medea adlı oyununun yeni bir uyarlamasını yapan Brendan Kennelly, bu trajediyi, olay örgüsüne bağlı kalarak ve ülkesindeki toplumsal problemleri işleyerek yeniden yorumlar.

Brendan Kennelly, ihaneti ve intikamı ele alan Medea'yı, alkol tedavisi gördüğü hastanede yazar. Orada kaldığı süreçte genellikle 17 ile 70 yaş aralığındaki kadınları dinler. Bu kadınların ortak noktaları, İrlandalı erkeklere duydukları öfkedir. Öfkelerinin en büyük sebeplerinden biri ise onları terk eden, reddeden ve onlara ihanet eden erkeklerin, yaptıklarının bilincinde dahi olmamalarıdır. Kadınların öfkeleri, erkeklerin y1llarca onları istismar etmelerinden ve hastanede ziyaretlerine bile gelmemelerinden kaynaklıdır. Kennelly, bu öfkeyi yeniden yorumladığı Medea'da göstermek istemiştir ve eserini kadınların bu öfke dolu sözlerinin etkisinde yazar.

Bu makalede, geçmişten günümüze varlığını sürdüren Medea mitosunun kaynaklık ettiği Euripides'in (İ.Ö. 485-406) Medea (İ.Ö. 431/2014) adlı oyununun çağdaş tiyatroda yansımasını bulduğu Brendan Kennelly'nin (1936-2021) (Bunu düzeltelim. Çünkü yazar Brendan Kennely 17 Ekim 2021 tarihinde vefat etmiştir.) Medea (1988) yorumlamasını ele almak amaçlanmıştır. Bu yeni varyasyonda, yazarın sistemde düzeltilmesi gereken sorunlara, toplum içerisinde var olan şiddete, ötekileştirmeye ve kadın erkek ilişkilerinin çıkmazlarına yönelik bakış açısı orijinal oyunla karşılaştırılarak incelenmektedir. Mitoslar, konu zenginlikleriyle yüzyıllar boyunca edebi eserlere kaynaklık etmiş ve sosyal sorunların incelenmesinde bir çerçeve olarak kullanılmıştır. Medea mitosu da kadını toplumdan soyutlama, farklılıkların ayrıştırılması ve baskıcı yapıların sonuçlarının incelenmesi açılarından zengin bir kaynak görevi görür. 


\section{Brendan Kennelly'nin Medea Yorumu}

Kennelly, Medea'yı yorumlarken zaman, mekân ve karakterlerde değişiklik yapmamıştır. Olay, yine Korinthos'ta Medea'nın evinde ve Antik Yunan Dönemi'nde geçmektedir. Oyundaki karakter sayısı ve isimler aynıdır. İki oyun arasındaki en büyük fark dize sayısındaki artıştır. Euripides'in 1419 dizelik oyununa karşılık, Kennelly'nin çevirisinde 2242 dize vardır. Böylece Kennelly, oyunun uzunluğunu yarısından fazla dize ekleyerek arttırmıştır. Bu ekleme ile güncel kaygıları ve İrlanda tarihindeki önemli gelişmeleri de oyununa dâhil etmiştir. Bu oyunda, Medea karakterinin çok yönlülüğünü ve derinliğini ifade eden tanımlamalar Euripides'in eserine göre daha fazladır:

\section{Sütnine:}

Kadınlar arasında Medea en kurnaz olanıdır.

Tilkidir o ve porsuktur, dağ gelinciğidir ve kakımdır.

Kartaldır ve de şahin,

Aynı kelimeleri kullanarak

Yedi çeşit konuşma yapabilir.

Güneşin bir türlü delip geçemediği bulut,

Bulutların karşısında duramadı ı̆ı güneştir.

Yağmurun sesidir o,

Okunmamış bir kitabın sessizliğidir. (2006: 79)

Kennelly'nin Medea'sı çok çeşitli tanımlamalarla sunulur. Medea'nın kurnazlığı, güçlü ve tehlikeli oluşu ayrıntılı olarak tasvir edilir. Kişilik betimlemesinde kullanılan hayvanlar ve doğa güçleri, onun yapabileceklerine yönelik merak uyandırır ve sözlerinin keskinliği konusunda uyarılar yapılır. Medea'nın marifetleri ve karakterinin keskinliği her yönüyle tasvir edilir. Bu şekilde tanımlanmasının amacı, Medea'ya yeni varyasyonda yüklenmiş olan anlamları artırmaktır. Euripides'in oyununda Sütnine, Medea'nın yaşadıklarına ve ıstırabına yoğunlaşırken, Kennelly'nin oyunundaki Sütnine, Medea'yı yaptıklarının bilincinde olan, dilini amacı doğrultusunda ustalıkla kullanan ve oyundaki diğer karakterleri yöneten kurnaz bir kadın olarak anlatır.

Kennelly, karakterlerine çağdaş özellikler yükler. Antik Yunan'da yaşamış bir Öğretmen, çağdaş tiyatro uyarlamasında günümüz tabirlerini kullanır. Euripides'in oyununda Öğretmen, herkesin kendini komşusundan daha çok sevdiğini üç dizede anlatırken, Kennelly'nin oyununda sözü uzatır ve konuyu farklılaştırarak otuz yedi dizeyle anlatır. Bunu yaparken eğitici bir üslupla seyirciye/okuyucuya ders vermeyi amaçlar. İfadeler mesaj yüklüdür ve günümüz insanına hitap eder şekilde sunulur:

\section{Öğretmen:}

(...) Gel, ben yüzyılları aşıyorum.

Bu sadece bir öğretmenin ayrıcalığıdır

-mesleğinin ilham ettiği delilik- 
Yüzyıllar geçtikçe, dudaklarındaki gülümseme

Dürüst, çaresiz tekrarları izlerken

Her şeyin aynı insanlara (hepsi ölse bile)

Aynı anda olduğu bilgisi. (Kennelly, 2006: 82)

Öğretmen'in bilgeliği ve yüzyılları aşabilmesi oyunun ölümsüzlüğüne yapılan bir göndermedir. Lala, yüzyılları aştığını söylerken Antik Çă̆’dan modern dünyaya ayak basabildiğini ima etmektedir. Kennelly, onu modern bir karakter olarak sergilemekte ve Antik Yunan seyircisiyle modern dünya insanının oyuna aynı anda tanıklık edebildiğini dile getirmektedir. Yüzyıllar geçse de insanların geçirdiği süreçler benzerlik göstermektedir. Yazar bu dizelerde Öğretmen'i, Antik Çă̆' da geleceğin diliyle konuşan bir karakter olarak kurgulamaktadır. Oyunda yer alan bu unsurlar ve karakterlerle Medea, kendi çağını aşmakta, çağdaş insanın yaşamını, duygularını ve sorunlarını yansitmaktadir.

Euripides'in Medea'sında mitolojik tanrılar, yeminler ve ilahi cezalandirmalara yapılan göndermeler yoğun olarak görülmektedir. Kennelly ise Medea'y1 yeniden yorumlarken tanrıların, mitolojik hikâyelerin anlatıldığı ve mitolojik ögelerin yoğunlukta olduğu kısımları oyundan çıkarmıştır. İason'un ihanetiyle dünyası yıkılmış ve öfkeden deliye dönmüş olan Medea, tanrılara seslenir ve ölmek istediğini söyler. Euripides'in oyununda Medea'nın yakarışlarına: “Ah Zeus! Ve Yeryüzü! Ve Işık! / Acılar içinde inleyen bir eşin ağıtını duyuyor musunuz? / Bu ne çılgınlık böyle? / Senin bunca arzuladığın döşek / Herkesin onca sakındığı döşek mi?” (Euripides, İ.Ö. 431/2014: 14) diye karşılık veren Koro, tanrılara seslenmiş ve Medea için yardım dilemiştir. Kennelly'nin oyununda ise Koro, Medea'yı ön plana çıkarır ve onun özelliklerini över: "Yaşa, sevgili Medea, yaşa / Sen güçlüsün, hayal gücün kuvvetlidir, beceriklisin / Eğer kocan başkasına âşık olmuşsa / Bu olağan bir şeydir. Şehrin her yerinde / Erkekler âşıklarına koşarlar ya da onları beklerler" (Kennelly, 2007: 36) diyerek yaşaması gerektiğini, Medea'nın güçlü karakterine ve meziyetlerine de vurgu yaparak isyanının ne kadar yersiz olduğunu ifade eder. Çünkü kadınların aldatılması toplumda artık yaygınlaşmış ve toplum tarafından kanıksanmıştır. Bu oyunda, Koro'nun Medea'nın aldatılmasına yaklaşımı farklıdır. Koro'ya göre Medea ile aynı durumda olan çok kadın vardır ve karısını terk eden bir adam için bu derece hayattan kopmak ve bundan sonraki hayatını hiçe saymak akıllıca bir davranış değildir. David Kovacs, Euripides'in Medea oyununun, çıkarları doğrultusunda hareket eden erkekler ve çıkarları feda edilen kadınlar arasındaki gerginlikleri gösterdiğini belirtir (1993: 51). Kennelly oyunun genelinde kadının aldatılmasına vurgu yaparak bunun artık daha yaygın olduğunu göstermek ister. Aynı zamanda, ihanete uğramanın sonucunda kendisini feda etmek ya da kaybedilenlerin ardından ağıt yakmak yerine, kadına kendisini keşfetmesini öğütler. Olumsuzlukların kadın için bir son olmadığını, kadınları güçlü durması gerektiğini ve sahip oldukları hayal gücü ve becerilerin onlar için yeni bir hayatın anahtarı olduğunu belirtir.

Kennelly, oyunda Medea'nın hitap ettiği kitleyi daha genel ifadelerle yansıtmıştır. Euripides’te Koro’ya “Korentli kadınlar!” (2014: 16) sözüyle seslenen Medea, çağdaş 
uyarlamasında "Bu şehrin kadınları" (Kennelly, 2007: 88) diye, zaman ve mekân sınırlandırması yapmadan, bütün kadınlara hitap ederek konuşmasına başlar:

Medea:

Eğer evlilik sağlam durursa,

Bir kadın ikinci bir gözleme ihtiyaç duyar,

Yatak arkadaşı olan yabancıyı idare edebilmek için.

(...)

Bir kadın gerçekten var olabilir mi,

Bir erkeğin ona gösterdiği ilgiden uzak? (Kennelly, 2007: 89)

Medea, kadınlara seslendiği bu kısımda, sürgün edildiği kentte kocası tarafından terk edilmenin verdiği acıyı ve ıstırabı dile getirir. Kadınların evlendikten sonra kocalarını mutlu etme ihtiyacı hissettiklerini söyler. Kennelly, Medea'nın konuşmasına Euripides'in oyununda var olmayan bir kısım eklemiştir. Kadın erkek ilişkisinin anlatıldığı bu bölümde, cinsel ilişki boyutu da oyuna taşınmıştır. Ataerkil toplum yapısında, evliliği ayakta tutabilmek için erkekten ziyade kadının çabalaması gerektiği vurgulanmıştır. Erkek terk edebilme ayrıcalığına sahip iken kadın, erkeğini elinde tutmak için çaba sarf etmesi gereken taraf gibi gösterilmiştir. Evlilikle birlikte erkeğin tahakkümü altına giren ve haksızlıklara maruz kalan kadın, evlilik hayatında kocasını mutlu etmek için yaşamalıymış gibi gösterilir. Kennelly, erkeği memnun etmek için çabalayan kadının yakarışını Medea'nın sözleriyle dile getirir. Ayrıca yaşadığı toplumda öteki konumunda gösterilen Medea'nın ve cinsiyet olarak geri plana itilen kadının düşünce ve duygularına yer verilmiş olur. İason'u bir yabancı olarak tanımlayan Koro, Medea'nın gözünden bakarak onu konunun merkezine koyar.

Kennelly, Medea'nın kişiliğini derinlemesine incelemiş ve oyundaki diğer karakterlerin, onu nasıl gördüğünü de detaylı bir şekilde sunmuştur. Medea'ya yöneltilen suçlayıcı ve kötüleyici ifadeler yoğunluktadır. Medea'nın yaptığı planlardan haberdar olan yeni gelinin babası Kreon, ona: "Korkuyorum senden. Gerçeği niye gizleyeyim? (...) / Zeki bir kadınsın, beceriklisin bir sürü şeytani sanatta" (Euripides, 2014: 18) der ve onun sürgün edilmesine karar verir. Kennelly'nin oyununda ise, bu sözlere ek olarak Kreon: "Gözlerin yanan delilik çukurları / Bedeninin her gözeneğinden kötülük sızıyor" (2007: 92) diyerek Medea'yı daha korkunç bir şekilde tasvir eder. Medea'nın türlü fedakârlıklarla çıktığı bu yolda mutlu bir hayat sürmesinin ayrıcalığı elinden alınmıştır ve o artık öfkesinden korkulması gereken bir kadındır. Buna rağmen Kennelly, öfkeyle hareket edilmemesi gerektiğine ve eski zamanlarda ve günümüzde karşılaşılan haksızlıkların ortadan kalkabileceğine dair umudunu kadınlara söz vererek kendi yorumuna Koro bölümüne şu şekilde ekler:

\section{Koro:}

(...) Bazı şeyler değişecek,

Cennetin sesi duyulacak. 
Ve kadınların haklı şanı yüzyılları süsleyecek (...)

Eşit neşeli akışla, onurun kadınlara verildiği,

Duygularını erkeklerin belirlemediği,

Köleliğin sevgi diye maskelenmediği,

Erkeğin ses tonunun kadının cevabında korku yaratmadığı,

Kadının değersiz bir adamı memnun etmek için yaşamadığı,

Sahibi kibirli, somurtkan düşüncelere dalmışken

Karısının onu sessizce beklemediği,

Kararların onaylanmadığı,

Nefretinin kendisini gösterebildiği,

Dile gelebildiği ve arındığı zaman gelecek.

Daha sonra belki adaletin gölgesi,

Dünyanın diğer ucuna ulaşır

Aynı sıcak bir hırkanın

Titreyen bir dilencinin omuzlarına atılması gibi. (2007: 97)

Erkeklerin, kadınlar üzerindeki etkilerini de oyununa katan yazar, kadınların hor görülüp ezildiğini ifade ederken, onların ilerde özgürleşeceği inancını da dile getirir. Kadınları ezen, aşağılayan ve onları erkeklerin istekleri doğrultusunda yaşamaya zorlayan unsurların zamanla yok olacağından bahseder. Burada kadının cesaretlendirilmesini ve gücünü göstermesini sağlamaya yönelik bir yaklaşım vardır. Bu yaklaşım, süregelen ataerkil düzenin değişmesi gerektiği anlamını içeren bir mesaj niteliğindedir.

Kennelly, bir erkek yüzünden bütün hayatı değişen Medea'yı farklı bir konuma taşır. $\mathrm{O}$, artık hem kadının yaşadığı zorlukların ve haksızlıkların simgesi hem de bir kadının yapabileceklerinin göstergesi olarak karşımızda durmaktadır:

\section{Koro:}

Yine de Medea,

Sen gerçek bir kadınsın,

Erkeğin "medenileştirmediği."

Kadınlardan korkan zayıf karakterli erkeklerin üstünlüklerini,

Uyuşuk ya da öfkeli güçlerini

“Erkekliklerini” göstermek için

şekil veremediğisin sen. "Erkekliklerini.”...

Bir külah ki erkeğin kafasını kapatmış, 
Böylece göremez, isteyerek kör olur.

Erkekliğini sorgulamayan adama ac1.

Erkeklik içgüdüsel kuvvet değildir.

Erkeklik kasti körlük değildir. (2017: 98)

Kennelly burada, Euripides'in oyunundaki feminist ögeleri açık bir şekilde dile getirmektedir. Koro, Kennelly'nin Medea'sında kadını tanımlayan ifadelere ek olarak kadınlara erkekler hakkındaki düşüncelerini ifade etme ayrıcalığını sunar. Euripides'in oyununda, kendini ifade etmeye henüz başlamış olan kadın, Kennelly'nin oyununda erkek egemen toplumu sert bir şekilde eleştirmeye başlamıştır. Koro'nun bu dönüşümü, iki oyun arasındaki belirgin bir farkı da göstermiş olur. Euripides kadının toplumdaki yerini sorgulamış fakat erkeği Kennelly kadar açık ve sert eleştirmemiştir. Her iki şairin yaşadığı dönemlerdeki toplum yapıları göz önüne alındığında, Euripides'in ataerkil düşüncelerin baskın olduğu bir çağda kadının sorunlarını gündeme getirmesi alışılagelmiş bir durum değildir. Kennelly'nin oyununda kadın haklarının savunulması ve erkek baskısının bu denli eleştirilebilmesinde Euripides'in Medea'yı güçlü bir kadın karakter olarak çizmesi etkili olmuştur.

İlerleyen sahnelerde İason, Medea'yla buluşunca yeniden evlenmekteki tek amacının çocuklarına soylu kardeşler yapmak ve onların geleceğini sağlama almak olduğunu söyler. Kennelly'nin oyununda, Medea'nın felaket içerikli dualarının farkında olan İason: "Tanrıya olan dualarını değiştirecek misin? (...) / En iyi dua / bu dünyanın aptallıklarıla ve kötülükleriyle / başa çıkmamıza yardım edendir" (2007: 105) diyerek Medea'ya öğüt verir. İason, sözcüklerini dua maskesinin ardına gizler. Medea ise karşıllı̆ında şu cevabı verir:

\section{Medea:}

Dua aptallarla başa çımak için değildir.

Dua başa çıkmak içindir;

Aptalların,

Güzel konuşan aptalların

Kör ve hırslı

Kuvvet açlığındaki ahmakların

Sebep oldukları haksızlıklarla.

Dua benim makul arkadaşımdır.

Olana duyduğum öfkem

ve olması gerekene duyduğum özlemimdir.

Dua şimdi senin kapında bir bombadır.

Mantıklı bir adam olarak sen, 
Sığınılacak bir saraya sahipsin.

Tutkularımı yaşarken ben,

Sürgünle yüz yüzeyim. (2007: 105-106)

Kennelly tarafindan eklenen bu bölüm onun siyasi düşüncelerini içerir. Şair, bu dizelerde İngiltere'nin İrlanda'yı sömürgesi altında tutmak için uyguladığı politikalara gönderme yaparak oyuna başka bir boyut katmaktadır. İngiltere'nin İrlanda'ya uyguladığı baskıcı, zulmedici ve sömürgeci politikaları oyununa yansıtan Kennelly, Medea'yı başkaldıran ve yaşadıklarının hesabını soran İrlanda olarak yeniden yorumlar. Medea'nın yakarışları ile gündeme gelen dua, dini boyutları aşarak İrlanda'nın bağımsızlık özlemini simgeler. Yapılan haksızlıklarla mücadele etme yöntemi olarak gösterilen dua simgesinin, güç peşinde koşan, açgözlü istilacılara yönelik olduğunu vurgulayan Kennelly, İrlanda'nın bağımsızlığını kazanmak için her şeyi göze aldığını dile getirir. Bir kadının ihanete uğramasıyla edindiği öfke, İrlanda halkının sömürge ve baskılara karşı duyduğu hiddetle bağdaştırılır. Böylece Medea, yaşadığı toplumu aşarak bir ezilmişlik sonucu oluşan tepkinin ve gösterilen mücadelenin simgesi olur. Bununla birlikte prensesin güzelliği ve ihtişamı; kralın gücü, sahip oldukları, yaşadıkları mutlu hayat bir anda bozguna uğrar ve düşmanlarının sinsi planıyla canlarını acı içinde kaybederler. Öyle ki öldüklerinde artık tanınmaz haldedirler. Bu durum, İrlanda halkının yaşadığı yıkımlarla savaşın, bombaların sonucunda karşılaşılabilecek görüntüyle bağdaştırılır. Bu benzetmeyle Kennelly, İrlanda'nın maruz kaldığı politik baskıları, bombalanmaları ve terörü vurgulamıştır.

İrlandalıları özgürlük tutkuları uğruna sürgünü göze alan bir halk olarak gösteren Kennelly, İngilizleri ise emperyalist bir krallık olarak niteler. Bu simgeleştirmeleri, İason ve Medea arasındaki konuşmalardan yararlanarak kurgulayan şair, böylelikle oyundaki olayların akışını da bozmaz. McDonald, Medea'nın verdiği cevapta Katolik kilisesi ve adalet duygusunun birbirine karıştı̆̆ını ve bu ifadelerin İrlanda'nın İngiltere'ye cevabı olarak da nitelendirilebileceğini söyler. Ona göre, Kennelly zekice bir hareketle İason'u Cromwell ${ }^{1}$ gibi konuşturur. İason/Cromwell barbarlara Protestan erdemlerini ve disiplinini dayatıcı nitelikte bir vaaz verir (McDonald, 1997: 85). Şair, Katolik ve Protestan kiliselerinin birbiriyle olan çekişmelerini, İason ile Medea arasında geçen tartışmalardan faydalanarak aktarır. İason, Medea'ya intikam içerikli yakarışlarını sonlandırmasını ve köşesine çekilip acısının son bulması için dua etmesini tavsiye eder. Ona göre, tepki göstermek yersizdir. Medea, kaderine rıza göstermelidir. Ancak o, yaşadığı yıkımı kabullenmez ve sınırlandırılmış kimliğini aşarak intikamını alır. Emperyalizm sorunuyla ilgilenen Kennelly, Medea'yı direnen ve intikamını almaya çalışan kadın olarak betimler (McDonald, 1997: 85). O, artık ezilen taraf olmayı bırakıp gücünü kanıtlayan taraf olmalıdır. Öyle ki Medea kendine olan inancını ve temsil ettiği değerleri: "Medea kadınların gerçek gücüdür. / Bu güç ki asırlardır zapt edilmiş, / üzeri örtülmüş. / Dindarlıkla köleleştirilmiş. / Hayır, ben güçsüz değilim” (Kennelly, 2007:

\footnotetext{
${ }^{1}$ Oliver Cromwell (1599-1658) Protestanlara Katolik kilisesinin inançlarını kanlı bir şekilde dayatmaya çalışan İngiltere'nin çıkarları için savaşan ve İrlanda'yı 1653 yılında kanlı bir savaşla yeniden fetheden askeri ve politik bir liderdir.
} 
147) sözleriyle ifade eder. Böylece, Medea, Kennelly'nin eserinde hem kadınların özgürlüğünü hem de İrlanda'nın bağımsızlığını simgeler.

Yazarın, oyunu kendi toplumuna adapte ederken ülkesinin içinde bulunduğu şartları yansıtması, olayları sorgulaması ve yıkımları göstermesi olağan bir durumdur. Kennelly'nin yeniden yorumladığı Medea, Antik Yunan Çağı'nda da toplumdan bağımsız bir şekilde yazılmamıștır. Euripides'in ifade şeklinin arkasındaki nedenler merak edilmiş ve oyun üzerine farklı fikirler yürütülmüştür:

Bu oyun üstüne son derece farklı yorumlar yapıldı, başka türlüsü de düşünülemezdi zaten. Örneğin politik olanı: Tam Peleponez Savaşı'nın eşiğinde (o yılın Dionüsialar'ından hemen sonra da savaş patladı zaten) Euripides, ihanetin, vefasızlığın buna sebep olabileceğini mi göstermek istedi acaba? Ya da, Barbarların neler yapabildiğini göstererek (İason'un dizesi 1339: "Bu cinayete cesaret edecek bir Yunanlı kadın bulunamazdı!") ulusal gururu mu pekiştirmek istedi? Biraz da psikolojik alandan yorumlar: İason gibi, hakiki sevgiyi asla tanımayan erkek cinsinin rezilliği mi sergilenmek istendi? Ya da, nedenlere kör kalıp salt eros ile yaşayan kadının temelde duygulara bağımlılığı $\mathrm{m}$ gösterilmek istendi? Böyle pek çok yorum yönelişlerini ve yorumları sıralayabiliriz. Hiçbiri de tümüyle haksız değildir. Ama birlikli bir anahtar anlamın peşine düşmek kesinlikle boşuna olur herhalde. Euripides, mitos'u normal insan dünyasına taşımış ve orada düşünceyi sonuna kadar götürmüştür. Araç ise mitos figürü olan Medea'nın özüdür. (Latacz, 2006: 278)

Joachim Latacz, Euripides'in toplumu sorgularken geçirilen dönemlerin ve içinde bulunulan şartların etkilerini göz ardı etmediğini anlatır. Euripides, bakışlarını insanın iç dünyasına yöneltmiş ve onun değişmeyen yaradılışına 1 şık tutmuştur. Yanlışları, doğruları, zaafları ve arzularıyla çizdiği evrensel insan portresi, onu günümüze kadar ulaştırmıştır. Böylelikle, yaşadığı dönemi aşarak çağdaşımız olmuştur. Bu durum, oyunun farklı bir ülkenin geçirdiği buhranlı y1llara uyarlanabilmesiyle gözlemlenmektedir.

Kennelly, Medea yorumunda Koro'ya büyük bir görev yükler. Antik Yunan oyunlarında halkın sesi olan ve çağın inanışlarını dile getiren Koro, Kennelly'nin oyununda, kadına hayatının ve bedeninin bütün hâkimiyetini ele geçirmesi konusunda tavsiyelerde bulunur. Çocuklarını öldürmeyi planlayan Medea, bu noktaya kadar sürekli yanında olup intikamını destekleyen Koro'nun artık yaşananlara dur diyen ve onu kararından vazgeçirmeye çalışan muhalif sesiyle karşı karşıya kalır:

\section{Koro:}

Sen sonsuza kadar çocuklarının katili Medea olacaksın.

Onları rahminde öldürmek daha merhametlice olurdu.

Kürtaj bir merhamet çeşidi olabilir. (Kennelly, 2007: 118)

Medea'nın çocuklarını öldüreceğini anlayan Koro, bunun çok büyük bir suç olduğunu dile getirir. Koro'daki kadınlara göre bir çocuğun yaşayıp yaşamamasına karar verilebilecek tek an, ana rahminde çok küçük bir cenin olduğu zamandır. Bu sözlerle, 
kadının kendi bedeni üzerinde söz sahibi olması gerektiği ve kürtajın bir seçenek olduğu vurgulanır. Anthony Roche'a göre “Kennelly'nin adaptasyonlarını yazdığı zamanın, İrlanda'nın kadın hakları ve kadınların kendi cinsel kimliklerini kürtaj ve boşanma kapsamında kontrol edebilmeleriyle ilgili tartışmalar ve referandumlarla kıvrandığ 1 dönem olan 1980'lerin ortası ve sonlarına denk gelmesi tesadüf değildir" (2005: 150). $\mathrm{Bu}$ dizelerle yazar, kendi ülke tarihine ve kadınların sorunlarına uzak kalmayıp kadının kendi bedeni üzerindeki hâkimiyetini her açıdan kazanması gerektiğini vurgulamaktadır.

Medea'nın çocuklarını öldürme düşüncesi devam ederken, Koro çocukları yetiştirmek ve geleceğe hazırlamak gibi konularla ilgili kaygılarını dile getirir. Her iki oyunda da çocuk sahibi olamamak bir eksiklik olarak ifade edilirken Kennelly, çocuk büyütmenin zorluklarını çağımızın sorunlarına uyarlayarak anlatır:

\section{Koro:}

Onları nasıl düzgün yetiştirebilirler?

Hangi okullara göndermelidirler?

Nasıl davranmalıdırlar onlara?

Nasıl otoriter olabilirler ve zalim gözükmezler?

Nasıl sabırlı olabilirler itaatsizlikle karşılaşınca?

Nasıl azarlayabilirler onları daha fazla uzaklaştırmadan?

Nasıl geçimlerini sağlayacaklar çocuklar, eğitim aldıktan sonra?

Ne yapılabilir onlar için eğitimsiz kalırlarsa (2007: 128).

Çocuğu olmayanlarla ebeveyn olanların karşılaştırıldığı kısımlarda Koro, çağın gerektirdiği çocuk yetiştirme usullerine dayalı sorular sorar. Anne ve babanın çocuk yetiştirirken yaşadığı ikilemleri, zorlukları ve kaygıları dile getirir. Euripides’ten farklı olarak Kennelly, çocukları okula göndermek ve onlara eğitim vermek gibi konuları da satırlarına ekler. Günümüzde ortaya çıkan kaygılar ve ailevi problemler, Medea'nın çağdaş yorumlamasına eklenmiştir. Aile ve çocuk ilişkisinde yaşanabilecekler ve çocuk yetiştirmenin zorluğu, çağdaş dönemin problemleri göz önüne alınarak anlatılmıştır.

Koro'nun karşı çıkışlarına ve onu ikna edebilmek için verdiği öğütlere rağmen Medea, intikamını tamamlamak için çocuklarını öldürür. Bu sahnede Kennelly, mitolojik ögelerin olduğu ve Koro'nun, çocuklarının katili olan Medea'yı zalim biri olarak nitelediği bazı bölümlere kendi yorumlamasında yer vermez. Euripides'in ifadeleriyle, çocuklarını öldürdükten sonra Medea'nın korkunç ve zalim yönleri çeşitli şekillerde vurgulanır. Koro ancak taştan ve çelikten bir kalbi varsa bir annenin doğurduğu bebeklerini öldürebileceğini söyler. İason da ağlayıp haykırdığında bu düşünceyi tekrarlar: "Böyle bir cinayetten sonra, böyle bir suçun iğrenç lekesi alnında / Ne yüzle bakabiliyorsun Güneş'e, Toprak'a?" (Euripides, 2014: 58-59). Ne var ki Medea yaşamaya devam eder ve düşmanlarından intikamını alarak eskisinden daha dik bir duruş sergiler. İason telafisi imkânsız bir acı içinde kıvranırken Medea özgürlüğe doğru yol alır. 
Oyunlarının sonları aynı olmakla birlikte iki yazarın birbirlerinden ayrıldıkları önemli bir nokta mevcuttur: Euripides'in tam anlamıyla belirtmediği Medea'nın zaferi, çağdaş oyunda Kennelly tarafından vurgulanır. Medea'yı İrlanda olarak simgeleştiren şair, Medea'nın zafere ulaşmasını da İrlanda'nın bağımsızlığını kazanması olarak gösterir. Roche'a göre, çağdaş yazarların adaptasyonları, trajedilerin sorduğu esas soruları adres göstermenin bir yoludur (2005: 151). Kennelly de oyunu bir soruyla noktalar:

\section{Koro:}

İşte hikâyenin sonu geldi.

Fakat merak ediyorum ve hep de edeceğim doğrusu

Medea'nın işlediği cinayet Medea'nın şanı mı oldu? (2007: 136)

Kennelly, Medea'yı yeniden yorumlayarak bu soruyu da cevaplamış olur. Medea ihanete uğradıktan sonra, onun düşüncelerini ve duygu dünyasındaki değişimleri anlamaya çalışırız. Yaşadıklarını ve planlarını kadınlık gururunun incitilmesine bağlarız. Fakat en sonunda çocuklarını öldürmesi onun anneliğini sorgulamamıza neden olur. Çocuklarının katili olmasaydı sadece intikam almak için cinayet işlemiş bir kadın olarak anılacaktı. Sahip olduğu şöhreti ona kazandıran, kaybettiği anneliği ve insanlığıdır. Medea'nın intikamında aşırılığa gitmesi ona trajik bir özellik kazandırır. Onun içinde bulunduğu durum toplumdan soyutlanamaz. $\mathrm{O}$, ihanet eden koca ve sürgün eden kral gibi dış güçlerin kıskacında kalır. Fakat eylemleriyle son sözü söyleme yetisinin olduğunu da kanıtlar. İnsani değerleri göz ardı ederek güçlü kalmanın yolunu bulur. Gerçek kimliğini ve özgür kişiliğini çocuklarını öldürerek bulur. Bu cinayet, kadını anne ve eş olarak tanımlayan topluma karşı direnişi simgeler. Erkek egemen toplum, kadını, annelik olgusuna hapsederek sınırlandırır. Medea ise kadına yüklenen toplumsal cinsiyet kavramını aşarak özgürleşir.

Aile düzeni ve birliği, eşlerin birbirlerine olan sadakati ve çocukların büyüdüğü ortam, toplumu birinci derecede etkileyen unsurlardır. GailAnn Rickert, Medea'nın yaptıklarını haklı gösterecek yeterli insani kanıt olmamasına rağmen, Euripides'in burada toplumu analiz ettiği gerçeğinin göz ardı edilmemesi gerektiğini "İason sadece karısının değil tanrıların ve toplumun aksine de hareket etmiş̧ir. Bir yemin bozucu olarak, sadece Medea tarafindan değer verilen bir eylemi değil sosyal düzenin temel bir ögesini de ihlal etmiştir” (1987: 91-117) diyerek vurgular. Euripides gibi Kennelly de bu olgulara vurgu yaparak sözünden dönmenin ve evlilik gibi kutsal bir kurumda özelikle kadın haklarının ve hayatının hiçe sayılmasının kabul edilemeyecek bir davranış olduğunu gösterir. İhanetle karşılaşınca kadının öfkesinin kaçınılmaz ve telafi edilemez sonuçlara yol açabileceğinin de altını çizer. Medea, "Biz kadınlar nazik, sıcak, düşünceli / yaratıklar olarak biliniriz. / Ama eğer varsa yapılacak korkunç bir şey, / bir kadının nazikliği / en öldürücü silahı olur" (Kennelly, 2007: 122) diyerek toplum tarafindan kadına yüklenen nezaket, düşünceli ve uysal olma gibi özelliklerin kadının yapabileceklerine yönelik beklentiyi düşürdüğünü vurgular. Kadının nazikliği zayıflık olarak görülür. Toplum, kadının bu özelliklerine yoğunlaştığı için kadının gerçek gücünü 
göremez. Böylece, bu oyunda kadın, beklenilenin aksine hareket ederek önüne konan engelleri aşar.

İncelediğimiz yeni Medea'da Kennelly, sadece esas aldığı oyundaki konuları işlemekle kalmaz aynı zamanda çağdaş dünyanın sorunlarını, insanların yaşam şekillerini, düşünce biçimlerini, evrensel konuları ve politik unsurları da oyununa ekler. $\mathrm{Bu}$ şekliyle Medea etkileyiciliğinden ödün vermeden günümüze uyarlanmış olur. Başına buyruk, kendi çıkarları doğrultusunda hareket eden İason, göz ardı ettiği, küçümsediği Medea'dan hayatının dersini almışıı. Kennelly ve Euripides, İason'un aldığı dersi oyunun sonunda "Tanrılar çeşit çeşit olayları sona erdirir, hiç beklenmedik bir sonla. / Olacağını sandığımız şeyler olmayıverir. / Hiç olamaz sandığımız şeyleri tanrılar mümkün kılar, yapıverir” (Euripides, 2014: 62) dizeleriyle dile getirmişlerdir. Hayatın türlü sürprizlerle dolu olduğunu, kimsenin gücünün yadsınmaması gerektiğini ve zulme uğrayanın elbet bir gün zulmedene verecek bir cevabının, öğretecek bir şeylerinin olduğunu vurgulamıştır. Medea, intikam almaya çalışırken kendisine zulmedenlerden daha zalim olmayı öğrenir. Haksızlığa karşı duruşun ve ihanete uğrayınca bir kadının neler yapabileceğinin göstergesi olur. $\mathrm{O}$, hem oyun içindeki karakterler hem de çağdaş seyirci/okuyucu üzerinde bir korku halesi oluşturur.

İhanet sonucu oluşan öfkenin yönettiği bir karakter olan Medea, yeni çağrışımların ve sorunların da ifade şekli olmuştur. McDonald'a göre "Kennelly öfkeye, özellikle kadının öfkesine, bir zafer şarkısı yazmıştır. Sadece 'İrlanda sorunu'2 gibi çağdaş konuları değil kadın ve erkeği kuşatan sevgi gibi evrensel konuları da ele alır" (1997: 305). Kennelly'nin Medea yorumu, hem İrlanda'nın yorucu, emektar geçmişindeki direnişe ve politik savaşına gönderme yapar hem de ötelenen 'kadın' sorununa evrensel bir açıdan yaklaşımlarda bulunur. Medea, öfkesini zaferle taçlandırır ve bu Kennelly tarafından İlanda'nın bağımsızlık ve refah içinde yaşamak uğruna verdiği mücadelenin bir benzeri olarak sunulur. Oyunu politik amaçlar ve yargılamalarla işlerken aynı zamanda kadının süregelen ezilmişliğini ve yenilgiye uğratılmasını da vurgular. Böylelikle, Kennelly İngiltere'nin İrlanda üzerindeki yıkıcı politikalarını ve İrlanda'nın sömürgecilik baskılarına karşı dışavurumunu tasvir ederek İrlanda'nın geçtiği zorlu dönemlere bir gönderme yapar. Ayrıca, İngiltere'nin İrlanda'yı sömürmesi ile erkeğin kadını sömürmesi arasında bir bağ kurar. Kadının erkeğin boyunduruğundan çıkmak için bağımsızlık mücadelesi vermesi İrlanda ile bağdaştırılır.

Kennelly oyununda, incitilmiş ve kızgın kadınların sesini duyurmaya çalışmaktadır. İlandalı erkekler tarafindan hayal kırıklığına uğratılan kadınlar, erkeklerin kadınlara yönelik incitici hareketlerinin bilincinde olmadıklarını dile getirir. Kennelly, kadınların erkeklerdeki bilinç eksikliğinden yakınmalarına vurgu yapar. Yapılan yanlışların

2 İrlanda Sorunu, Katolik İrlanda Halkının ve İrlanda adasının 1600'lü y1lların başlarında İngilizlerin ve İskoçların yönetimine girmesiyle başlar. İrlanda krallıklarını Birleşik Krallık'ı oluşturmak için Büyük Britanya ile birleştiren ve parlamentolarını tek bir yönetim organı olarak organize eden 1800 Birlik Yasası sonucunda ortaya çıkmıştır. Kuzey İrlanda'nın anayasal durumu ve iki ülke arasındaki siyasi ilişkiler sonunun temel parçalarıdır (Boyce, 1988: 1). 
bedelinin ağır olacağını ve istismar edilen kadının öfkesinden korkulması gerektiğini öğütler. Medea'nın sonu Kennelly'nin tecrübeleri doğrultusunda şekillenir. Daha önce belirtildiği gibi hastanede tedavi gördüğü sırada oyunu yazan Kennelly, hayata yeniden tutunmanın zaferini ve İrlanda'nın bağımsızlık içinde varlığını sürdürmesini Medea'nın yeni bir hayata başlamasıyla bağdaştırır. Euripides'in Medea'sından kendi oyununa geçişi ise şu sözlerle ifade eder:

Benim kurgulamaya çalıştığım Medea makul, hırslı, konuşkan ve ne istediğini, istediğini nasıl elde edeceğini bilen, İason tarafindan aldatılmasının bilincinde olmanın ıstırabını çeken modern bir kadındır. Kafamda canlandırdığım Medea, İason'u korkunun bilinçliliğiyle eğitmeye çalışır, onun dünyasını yıkar fakat onu sağlam bırakır ve soğukkanlıııkla ve açık bir şekilde sağlamlığının sonuçları hakkında onu bilgilendirir... Gördüğüm kadarıyla Medea, İason'un üzerine en büyük zalimliği yıkar, onu hayata mahkûm eder. Oyun farklı yollara giden, kendileriyle yaşamak zorunda kalan iki insan arasındaki korkunç ve serinkanlı konuşmayla son bulur. Fakat yaşanan sonun İason için daha çetin olacağı algılanır. (2007: 71)

Yaşadığ 1 ihanetin ardından, hayata tutunma gücü bulamayan Medea, bütün kadınların, özellikle İrlandalı kadınların, sözcüsü ve eylemcisi konumundadır. Medea, kocasını dünyanın bütün güzelliklerinden mahrum etmenin yollarını ararken ihanete uğramanın verdiği öfkenin kıskacındadır. Başlangıçta intikam almaktan başka hiçbir şey düşünmeyen Medea'nın yaptıklarının nedeni İason'un ihanetidir. Bu durum, erkek egemen toplumun Medea üzerinde kurduğu baskının sonuç verdiğini gösterir. Kennelly, Medea'yı bu öfke nedeniyle suçlamak yerine onun hakl1lığını vurgular. Çünkü ona göre, haksızlığa uğrayan kadının tepki göstermesi kaçınılmazdır. Öfkesinin sonuçları yıkıcı olacaktır. Euripides'in oyununda Medea, kadının ihanete uğramasıyla korkusuz olacağını "Bir kadın zayıf ve ürkektir pek çok işte: / Korkutur onu, savaşın gürültüsü, çeliğin görüntüsü. / Ama evlilikteki haklarına bir dokun da gör, var mı ondan daha kanlısı" (2014: 18) dizeleriyle belirtir. Kennelly, James Morwood'un “Antik edebiyatın en feminist ifadesi" (1997: 171) olduğunu iddia ettiği bu dizeleri, Medea yorumunun tamamına genelleyerek sunar. Bu şekilde Kennelly, kahramanını susup geri çekilen kurban sıfatından sıyırarak tepki gösteren, hakkını savunan ve itibarını geri kazanmaya çalışan bir kadın savaş̧̧ kimliğine bürür.

Kennelly'nin Medea karakteri, daha korkusuz ve özgürdür. Yazarın, ona bu özgürlüğü kazandırmasının sebebi, hem kadınları hem de İrlanda halkını cesaretlendirmek istemesindendir. Kendi ülkesinde yaşananlardan yola çıkarak dünya kadınını savunan Kennelly, İrlanda'da politik mücadelenin geldiği noktayı, devinimleri ve kadının geçmişten günümüze içinde bulunduğu durumu gündeme getirir. Kadın, bağımsızlı̆ğı kazanmak ve ataerkil toplum tarafından ona yüklenen sınırlayıcı vasıfları aşmak için mücadele eder. Burada Kennelly, Medea'yı İrlanda olarak simgeleyerek bağımsızlık için verilen mücadelede İrlandalıların her şeyi göze aldığını vurgular. 


\section{Sonuç}

Mitoslar, insanların iç dünyalarını, yaşantılarını, inanışlarını ve manevi değerlerini yansıtan; birbirleriyle ve kâinatla olan ilişkilerini düzenleyen ve böylece toplumda ortak bir bilinç oluşturan öykülerdir. Eski insanların hisleri ve algıları doğrultusunda deneyimledikleri evrendeki ögelerin bir araya gelmesiyle oluşan mitoslar, zamanla kendi içinde bir düzene sahip olan öğretilere dönüşür.

Antik Yunan mitolojisinin en etkileyici kadın karakterlerinden biri olan, yirmi birinci yüzyıla kadar farklı biçimlere bürünüp karşımıza çıkan, gücü ve soğukkanlılığıyla ünlü, barbar prenses Medea'nın etrafında şekillenen Medea mitosu, Antik Çăg'da ve sonraki dönemlerde birçok kez yeniden yorumlanmıştır. Medea mitosunu yeniden yorumlayarak Medea adlı oyunu yazan Euripides, efsanedeki tanrısal eylemleri azaltarak gücü insanın eline vermiştir. Ayrıca, bir ozan olarak, oyununa sahip olması gereken etkileyiciliği kazandırmak ve yazdığı oyunla seyirciye arzu ettiği şekilde tesir edebilmek için mitosta değişiklikler de yapmıştır.

Medea, mitosta çoğunlukla bazı tanrısal bağı ve büyü gücüyle ön planda iken Euripides'in oyununda gerçek dünyayla daha yoğun bir ilişki içerisinde olan ve temel insani duyguların hâkimiyetinde hareket eden bir kadın olarak karşımıza çıkar. Euripides, sürgün edilen ve toplumdan dışlanan kadının, yabancı olduğu bir ülkede ihanete uğraması sonucunda gurur ve öfke duygularıyla hareket edişini tasvir eder. Ataerkil düzende kadına yüklenen toplumsal kimliği gösterirken çağdaşlarının ve dönemin düşünce yapısının aksine kadının mevcut düzene direnişini ve gerçek kimliğini ortaya çıkarışını da gösterir. Böylece kadını; öfkesi, hırsı ve toplumun alışkın olmadığı şekilde erkeklerle olan ilişkisiyle sahneye taşıyan Euripides, insan yapısını tüm çıplaklığıyla ve göz ardı edilen gerçekliğiyle analiz eder. Euripides'in Medea adlı oyunu, kendi dönemini aşarak günümüze kadar varlığını sürdürür.

İrlandalı yazarlar ${ }^{3}$, ülkelerindeki bağımsızlık mücadelesini ve kadın sorunsalını ele alırken mitoslardan sıklıkla yararlanmışlardır. Euripides'in çizdiği Medea karakterinin İrlandalı yazarlara cazip gelmesinde kadının, bağımsızlı̆̆ İrlanda kültürüne ve tarihin uygulanabilir olmasının etkisi büyüktür. İrlandalı yazarlar, Medea'yı toplumsal konular üzerine yorum yapmak ve fikirlerini belirtip çözüm önerileri sunmak için yeniden yorumlamışlardır.

İrlanda'nın en verimli ve popüler şairlerinden biri olan Brendan Kennelly, Euripides'in Medea oyununu yeniden yorumlarken ülkesinin içinden geçtiği zorlu dönemleri anlatmış; İrlanda kadınının sorunlarını dile getirerek onları bilinçlendirmeye ve cesaretlendirmeye yönelik simgelere yer vermiştir. Kennelly, oyunda, Medea'nın karakterinin çok yönlülüğünü ve derinliğini ifade eden tanımlamalara yer vermiş, kadın ve aile kavramıyla ilgili güncel kaygıları dile getirmiş ve İrlanda tarihinde yer alan önemli gelişmeleri simgeleştirerek sunmuştur. Bunları yaparken, Euripides'in

\footnotetext{
${ }^{3}$ Tom Paulin (1949- ), W. B. Yeats (1865-1939), Seamus Heaney (1939-2013), Marina Carr (1964- ), Frank McGuiness (1953- ).
} 
Medea'sına yarısından fazla dize eklemiş böylece yorumlamasını oyunu uzatarak sunmuştur.

Kennelly, İngiltere'nin İrlanda'yı sömürgesi altında tutmak için uyguladığı politikalara gönderme yaparak oyuna siyasi bir boyut katmıştır. Medea'yı başkaldıran ve yaşadıklarının hesabını soran bir İrlanda simgesi olarak yeniden yorumlarken, bir kadının ihanete uğramasıyla edindiği öfkeyi, İrlanda halkının sömürge ve baskılara karșı duyduğu hiddetle bağdaştırmıştır. Oyunu politik amaçlar ve yargılamalarla işlerken aynı zamanda kadının süregelen ezilmişliğine de vurgu yapar. Kendi ülkesinde yaşananlardan yola çıkarak dünya kadınını savunan Kennelly, İrlanda'da politik mücadelenin geldiği noktayı, devinimleri ve kadının geçmişten günümüze içinde bulunduğu durumu gündeme getirmiştir. Kennelly, oyunu çağdaş İrlanda toplumuna uyarlarken güncel kaygıları, çağdaş toplum yapısını ve kadının toplumdaki yerini analiz etmiştir. Medea'yı İngiltere sömürgesinden kurtulup bağımsızlığını kazanan İrlanda olarak betimleyen yazar, İrlanda halkı tarafindan gösterilen direnişin kutsallığını Medea'nın öfkesi ve mücadelesiyle ilişkilendirmiştir. Yazarın düşünceleri ve yaşadığı toplumun kültürel etkileriyle şekillenen bu yeni varyasyonda, İrlanda'nın geçirmiş olduğu süreçlerin bu ülkenin vatandaşları üzerindeki etkilerinin, Medea'nın yaşadıklarıyla ilişkilendirilerek sunulduğu gözlemlenmiştir.

\section{Kaynaklar}

Boyce, D. G. The Irish question and British politics: 1868-1986. St. Martin's Press, Inc. Clauss, J. J., \& Johnston, S. I. (Eds.). (1997). Medea: Essays on Medea in myth, literature, philosophy, and art. Princeton University Press.

Dillon, J., \& Wilmer, S.E. (Eds.). (2005). Rebel women: Staging Ancient Greek drama today. Methuen.

Euripides. (2014). Medea (M. Balay, Çev.), Mitos Boyut Tiyatro Yayınları. (Orijinal çalışma yayınlandı MÖ 431)

Kennelly, B. (2006). When then is now: Three greek tragedies, Bloodaxe Books.

Kovacs D., "Zeus in Euripides' Medea" The American Journal of Philology, 114(1), 1993, 45-70.

Latacz, J. (2006). Antik yunan tragedyaları (Y. Onay, Çev.), Mitos-Boyut Tiyatro Yayınları. (Orijinal çalışma yayınlandı 1993)

McDonald, M. (2006). "War then and now: The legacy of Ancient Greek tragedy. Hermathena, 181, 83-104.

Morwood, J. (1997). Oxford world classics: Euripides' Medea and other plays. Oxford University Press.

Rickert, G. (1987). Akrasia and Euripides' Medea. Harvard Studies in Classical Philology, 91, 91-117.

Roche, A. (2005). "Kennell's Rebel Women". (Ed. John Dillon, S.E.Wilmer). Rebel Women: Staging Ancient Greek Drama Today. Great Britain: Methuen. (ss. 149168). 